\title{
IoT Smart Energy Meter Monitoring with Web and Blynk App
}

\author{
Arpanbhai Patel, Dhwani Darji
}

UG Scholar, Sardar Vallabhbhai Patel Institute of technology, Vasad, Vadodara, Gujarat, India

\begin{abstract}
Article Info

Volume 7, Issue 4

Page Number : $125-131$

Publication Issue :

July-August-2021

\section{Article History}

Accepted : 02 July 2021

Published : 09 July 2021

Electricity is a crucial innovation that would render life on Earth impossible. As a result, there is a clear requirement to track the amount of power used. The wattmeter does this, but a GEB representative must visit each customer's home to evaluate power use and estimate the bill amount. As a result, it entails a lot of physical labor and takes time. We planned to build an IoT-based energy meter for each of GEB's customers. As a result, the suggested energy meter monitors the amount of power utilized and uploads it to the Thingspeak cloud, where the reading may be viewed by the person concerned. ESP 8266, a Wi-Fi module, can be used to send the power reading to the cloud. The opt coupler analyzes the power reading from the digital wattmeter and feeds it digitally to the Arduino. As a way, it uses IoT to automate the process of measuring energy usage at households, allowing remote access and digitalization for each GEB subscriber.

Keywords : Internet of Things, NodeMCU ESP8266, PZEM-004T, Blynk, HTML.
\end{abstract}

\section{INTRODUCTION}

Smart metering is the monitoring the electricity consumption through modern metering devices connected to the Internet via IoT technology. ... Smart meters, which collect consumption data and periodically send it to a central server for processing. And via internet anyone from any part of the world can monitor and control the loads through their handsets. It consists different methods like GSM communication, Real time clock, Internet of things (IoT), Automatic Meter reading etc.

Current Problems with Normal energy meter:

- Government officer have to go Door to door for meter reading.

- People don't get to know their bill until it comes.
- If any problems occurred then they don't able to cut off the loads remotely.

- one cannot track their usage and spend

- cannot Monitoring the electric system and its fault.

- Increasing the number of frauds.

Advantages: -

- The electric utility may profit from smart meters.

- Eliminating manual measurements

- Increasing the speed with which the electric system is monitored

- Allowing more effective use of power resources

- Providing real-time data useful for balancing electric loads and reducing power outages (blackouts) 
- Enabling dynamic pricing (increasing or decreasing the cost of electricity dependent on demand)

- Assisting in the optimization of income with existing resources

- You won't have to submit metre readings

- You'll be able to keep a careful eye on your spending and use

- You'll get accurate invoices instead of guesswork!

Disadvantages:-

- Transitioning to new technology and processes

- Managing public response and consumer adoption of the new meters.

- Making a long-term financial commitment to the new metering technology and accompanying software . Managing and storing vast quantities of metering data

- $\quad$ Ensuring the safety of metering data.

- Older meters become "dumb" as you switch

- Poor signal

Pzem-004t is used as electrical parameter measurement function (voltage, current, active power). 4 piece display function (display voltage, current, active power). The serial communication function (comes with TTL serial interface, via various terminals communicate with the adapter plate, read, and set the parameters). PZEM-004T AC communication module, the module is mainly used for measuring AC voltage, current, active power, frequency, power factor and active energy, the module is without display function, the data is read through the TTL interface.

PZEM-004T-10A: Measuring Range 10A (Built-in Shunt)

PZEM-004T-100A: Measuring Range 100A (external transformer)

Voltage: Measuring range: $80 \sim 260 \mathrm{~V}$, Measurement accuracy: $0.5 \%$. Active power: Measuring range: $0 \sim$ 2.3kW(PZEM-004T-10A); $0 \sim 23 \mathrm{~kW}$ (PZEM-004T$100 \mathrm{~A})$. Starting measure power: $0.4 \mathrm{~W}$. Power factor: Measuring range: $0.00 \sim 1.00$, Measurement accuracy: 1\%. Frequency: Measuring range: $45 \mathrm{~Hz} \sim 65 \mathrm{HZ}$, Mmeasurement accuracy: 0.5.

\section{Work Done Till Date}

Table 1. Previous Related Works

\begin{tabular}{|l|l|l|l|l|}
\hline Authors & Year & Methods & Advantage & Limitation \\
\hline $\begin{array}{l}\text { Amrita Singh } \\
\text { and et. All }\end{array}$ & 2018 & $\begin{array}{l}\text { ESP8266, } \\
\text { HTML, Java }\end{array}$ & $\begin{array}{l}\text { Energy unit reading is } \\
\text { accurate. }\end{array}$ & $\begin{array}{l}\text { Need Java language } \\
\text { Knowledge. } \\
\text { Not Provided } \\
\text { Mobile View. }\end{array}$ \\
\hline $\begin{array}{l}\text { Win Adiyansyah } \\
\text { Andra, Fatimah Bt } \\
\text { Morad, et all }\end{array}$ & 2018 & $\begin{array}{l}\text { Real Time Clock } \\
\text { (RTC), } \\
\text { Mobile } \\
\text { Communication } \\
\text { (GSM), } \\
\text { Automatic Meter } \\
\text { Reading (AMR), }\end{array}$ & $\begin{array}{l}\text { Customers have the } \\
\text { ability to monitor their } \\
\text { current bill or power } \\
\text { ansumption from } \\
\text { anywhere. }\end{array}$ & $\begin{array}{l}\text { Users cannot } \\
\text { usage, power } \\
\text { consumptions by } \\
\text { themselves } \\
\text { remotely from their } \\
\text { mobile phones }\end{array}$ \\
\hline Lavanya Garg & 2018 & (FDI) Fault & The bill can be paid in & Need of utilization \\
\hline
\end{tabular}


Arpanbhai Patel et al Int. J. Sci. Res. Comput. Sci. Eng. Inf. Technol, July-August-2021, 7 (4) : 125-131

\begin{tabular}{|c|c|c|c|c|}
\hline $\begin{array}{l}\text { and } \\
\text { Charul Sharma }\end{array}$ & & $\begin{array}{l}\text { Detection } \\
\text { Isolation, } \\
\text { Internet of } \\
\text { Things, } \\
\text { (IoE), } \\
\text { (IoT) }\end{array}$ & $\begin{array}{l}\text { advance. In case any } \\
\text { technical difficulty } \\
\text { occurs, that would be } \\
\text { notified to the user. It } \\
\text { offers to check the power } \\
\text { consumption remotely. }\end{array}$ & $\begin{array}{l}\text { of vitality meter } \\
\text { which can be used } \\
\text { in various space } \\
\text { whenever there's } \\
\text { deficiency of } \\
\text { power. }\end{array}$ \\
\hline $\begin{array}{l}\text { Pooja D Talwar1 } \\
\text { And } \\
\text { Prof. S B } \\
\text { Kulkarni }\end{array}$ & 2016 & $\begin{array}{l}\text { Automatic Meter } \\
\text { Reading (ARM), } \\
\text { WIFI ESP8266 } \\
\text { module }\end{array}$ & $\begin{array}{l}\text { reducing energy } \\
\text { consumption in house, } \\
\text { generate bill } \\
\text { automatically }\end{array}$ & $\begin{array}{l}\text { There must be } \\
\text { installed WIFI } \\
\text { hotspots in each } \\
\text { area. }\end{array}$ \\
\hline $\begin{array}{l}\text { K. Lova Raju } \\
\text { And K. } \\
\text { Yaswanth } \\
\text { Pavankalyan, et } \\
\text { all }\end{array}$ & 2020 & $\begin{array}{l}\text { Automatic Meter } \\
\text { Reading (ARM), } \\
\text { internet of } \\
\text { things (IOT) }\end{array}$ & $\begin{array}{l}\text { Keep tracks of consumer } \\
\text { load and keeps energy } \\
\text { unit handy. }\end{array}$ & $\begin{array}{l}\text { needs to develop } \\
\text { web application }\end{array}$ \\
\hline $\begin{array}{l}\text { MARTIN } \\
\text { MISKUF } \\
\text { And ERIK } \\
\text { KAJATI }\end{array}$ & 2017 & $\begin{array}{l}\text { real-time } \\
\text { monitoring, } \\
\text { internet of } \\
\text { things (IOT) }\end{array}$ & $\begin{array}{l}\text { We can identify running } \\
\text { appliances and its } \\
\text { consumption patterns, } \\
\text { this system having fault } \\
\text { detection so we can easily } \\
\text { find out fault occurs in } \\
\text { system. }\end{array}$ & $\begin{array}{l}\text { Privacy is a big } \\
\text { issue. All the data } \\
\text { must be encrypted. }\end{array}$ \\
\hline $\begin{array}{l}\text { D. V. N.Ananth } \\
\text { And G. Joga Rao, } \\
\text { et all }\end{array}$ & 2019 & $\begin{array}{l}\text { GSM, internet of } \\
\text { things (IOT) }\end{array}$ & $\begin{array}{l}\text { The energy smart meter } \\
\text { gives accurate reading of } \\
\text { energy used by } \\
\text { customers., It shows time } \\
\text { to time power utilization } \\
\text { of the load/loads } \\
\text { connected to the system. }\end{array}$ & $\begin{array}{l}\text { There are several } \\
\text { opportunities for } \\
\text { failure with } \\
\text { complex systems. }\end{array}$ \\
\hline $\begin{array}{l}\text { Birendrakumar } \\
\text { Sahani and } \\
\text { Tejashree Ravi } \\
\text {, et all }\end{array}$ & 2017 & $\begin{array}{l}\text { Internet of } \\
\text { things (IOT), } \\
\text { GSM }\end{array}$ & $\begin{array}{l}\text { It reduces the wastage of } \\
\text { energy and bring } \\
\text { awareness; Monthly } \\
\text { consumption of power } \\
\text { will be sent as message to } \\
\text { the consumer with total } \\
\text { bill of electricity }\end{array}$ & $\begin{array}{l}\text { After threshold } \\
\text { value the loads will } \\
\text { be automatically } \\
\text { switch ON or OFF. }\end{array}$ \\
\hline $\begin{array}{l}\text { Somchai } \\
\text { Thepphaeng } \\
\text { And }\end{array}$ & 2017 & $\begin{array}{l}\text { Internet of } \\
\text { things (IOT), } \\
\text { Realtime clock }\end{array}$ & $\begin{array}{l}\text { A solution is a low-cost, } \\
\text { simple-to-implement, and } \\
\text { easy-to-manage energy }\end{array}$ & complications steps \\
\hline
\end{tabular}




\begin{tabular}{|c|c|c|c|c|}
\hline $\begin{array}{l}\text { Varunyou } \\
\text { Nontaboot }\end{array}$ & & (RTC) & $\begin{array}{l}\text { monitoring system for } \\
\text { our daily use of } \\
\text { electricity. This } \\
\text { eliminates human errors, } \\
\text { manual labor, and lowers } \\
\text { energy consumption costs } \\
\text { while increasing } \\
\text { efficiency. }\end{array}$ & \\
\hline $\begin{array}{l}\text { Rishabh Jain } \\
\text { And Sharvi } \\
\text { Gupta,et all }\end{array}$ & 2019 & $\begin{array}{l}\text { Internet of } \\
\text { things (IOT), } \\
\text { Automatic Meter } \\
\text { Reading System } \\
\text { (ARMS) }\end{array}$ & $\begin{array}{l}\text { To reduce wastage of } \\
\text { energy, Prevent } \\
\text { electricity shortage } \\
\text { during dry seasons. }\end{array}$ & $\begin{array}{l}\text { The system is } \\
\text { mainly intended for } \\
\text { smart cities with } \\
\text { public Wi-Fi } \\
\text { hotspots. If net } \\
\text { connection lost } \\
\text { then don't work } \\
\text { properly }\end{array}$ \\
\hline $\begin{array}{l}\text { M. M. } \\
\text { Mohamed } \\
\text { Mufassirin } \\
\text { And A. L. } \\
\text { Hanees }\end{array}$ & 2018 & $\begin{array}{l}\text { Internet of } \\
\text { things (IOT), } \\
\text { Automatic Meter } \\
\text { Reading System } \\
(\mathrm{ARM})\end{array}$ & $\begin{array}{l}\text { Detect and control the } \\
\text { energy theft., } \\
\text { consumptions are } \\
\text { calculated automatically. }\end{array}$ & $\begin{array}{l}\text { Chances of failure } \\
\text { of digital } \\
\text { equipment's and } \\
\text { corrupts the data. }\end{array}$ \\
\hline $\begin{array}{l}\text { K. Lova Raju and } \\
\text { K. Yaswanth } \\
\text { Pavankalyan,et } \\
\text { all }\end{array}$ & 2020 & $\begin{array}{l}\text { Internet of } \\
\text { things (IOT), } \\
\text { Real time } \\
\text { application }\end{array}$ & $\begin{array}{l}\text { energy unit reading can } \\
\text { be handy, } \\
\text { save and manage power. }\end{array}$ & $\begin{array}{l}\text { implementation of } \\
\text { this system is } \\
\text { complex. }\end{array}$ \\
\hline $\begin{array}{l}\text { Shahajan Miah } \\
\text { And G.M. } \\
\text { Jahedul Islam,et } \\
\text { all }\end{array}$ & 2019 & $\begin{array}{l}\text { Internet of } \\
\text { things (IOT), } \\
\text { convectional } \\
\text { method }\end{array}$ & $\begin{array}{l}\text { minimize the technical } \\
\text { mistakes, } \\
\text { transfer data over a } \\
\text { network without human } \\
\text { interactions. }\end{array}$ & $\begin{array}{l}\text { Complicated } \\
\text { operations. }\end{array}$ \\
\hline $\begin{array}{l}\text { Satien Janpla1 } \\
\text { and Chaiwat } \\
\text { Jewpanich ,et all }\end{array}$ & 2020 & $\begin{array}{l}\text { Internet of } \\
\text { things (IOT), } \\
\text { Automatic Meter } \\
\text { Reading (AMR) }\end{array}$ & $\begin{array}{l}\text { Smart power outlet., } \\
\text { Calculate power } \\
\text { consumption }\end{array}$ & $\begin{array}{l}\text { Continuous power } \\
\text { supply to the } \\
\text { Arduino and wife } \\
\text { module. }\end{array}$ \\
\hline V.Badri Rama & 2019 & Internet of & Maximum use of energy & Some steps are \\
\hline
\end{tabular}




\begin{tabular}{|l|l|l|l|l|}
\hline $\begin{array}{l}\text { Krishnan and } \\
\text { Keerthana } \\
\text { Sandepudi, et all }\end{array}$ & $\begin{array}{l}\text { things (IOT), } \\
\text { real time } \\
\text { application }\end{array}$ & $\begin{array}{l}\text { sources in cheapest way, } \\
\text { Smart energy } \\
\text { management. }\end{array}$ & complicated. \\
\hline $\begin{array}{l}\text { Md Redwanul } \\
\text { Islam and } \\
\text { Supriya Sarker, } \\
\text { et all }\end{array}$ & 2019 & $\begin{array}{l}\text { Internet of } \\
\text { things (IOT), } \\
\text { Automatic Meter } \\
\text { Reading (ARM) }\end{array}$ & $\begin{array}{l}\text { The goal is to reduce } \\
\text { manual labour and } \\
\text { human error when } \\
\text { measuring electricity } \\
\text { units. }\end{array}$ & $\begin{array}{l}\text { implementation of } \\
\text { this system is } \\
\text { complex. }\end{array}$ \\
\hline
\end{tabular}

\section{Proposed System}

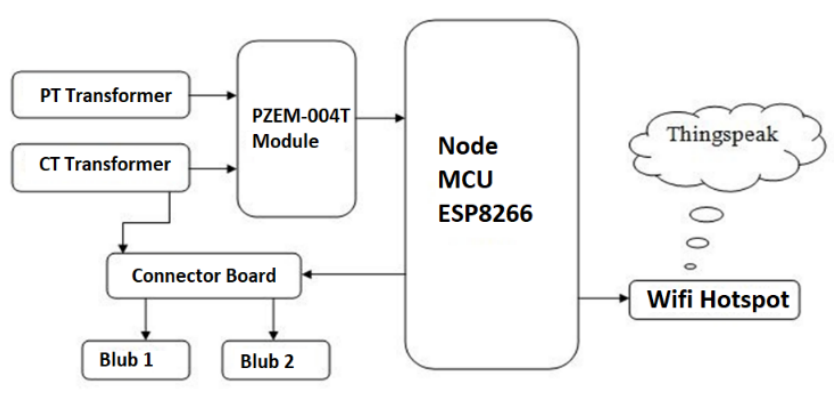

Figure 1. Block Diagram

The project's main goal is to create an IOT (internet of things)-based energy meter that displays units consumed and costs in a chart and gauge format over the internet. We used a digital energy meter for this ground breaking project in which Current and Power Transformer are interfaced to a microcontroller through a Signal Conditioning Board. The Signal Condition gives reading each time to the microcontroller when connected loads are ON. First, PZM-004T module takes this analogy reading and convert it into digital data then after it sends it to the cloud using ESP 8266. PZM-004T is a voltage and current reader with inbuilt current transformer which is interfaced with the microcontroller. Here, As a microcontroller, the ESP8266 is used. The data is serially transmitted from the ESP 8266 to the Thing speak web page, resulting in a multi-level graphical display that can be viewed from anywhere in the world. The PZM-004T module requires a 5V supply, while the ESP 8266 requires a $7.5 \mathrm{~V}$ adapter. In the same Arduino IDE, the ESP8266 is programmed using
ARDUINO software, and the Wi-Fi module is programmed using AT commands. On the Thing speak website, the consumed power reading is displayed in graphical and gauge format, along with the cost to be paid for consumption, Simulation and Circuit Diagram

In below circuit diagram we can observe that $220 \mathrm{~V}$ single phase power supply is connected with the current transformer of the PZM module. Current transformer is inbuilt connected with the PZM. PZEM-004TAC AC voltage, current, active power, frequency, power factor, and active energy are all measured with this module. And this PZEM module is interfaced with the Wi-Fi module ESP8266. All the current variation is measured by current transformer. Then after this variation of current and voltage analogy value is send to the microcontroller ESP8266. Microcontroller converts it into the digital binary value and then after it also be sent into the internet clouds from which we can see our consumption via webpage in our devices.

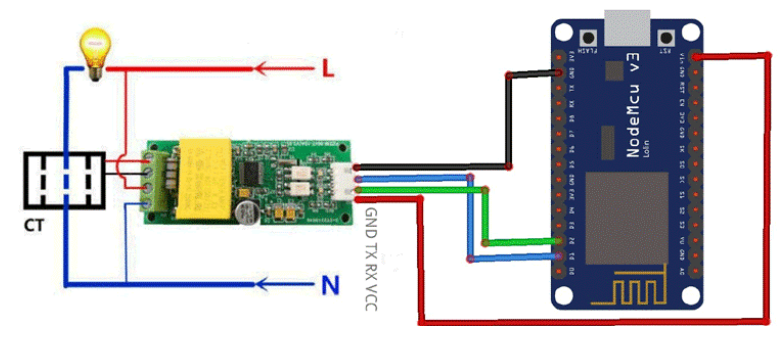

Figure 2. Circuit Diagram 


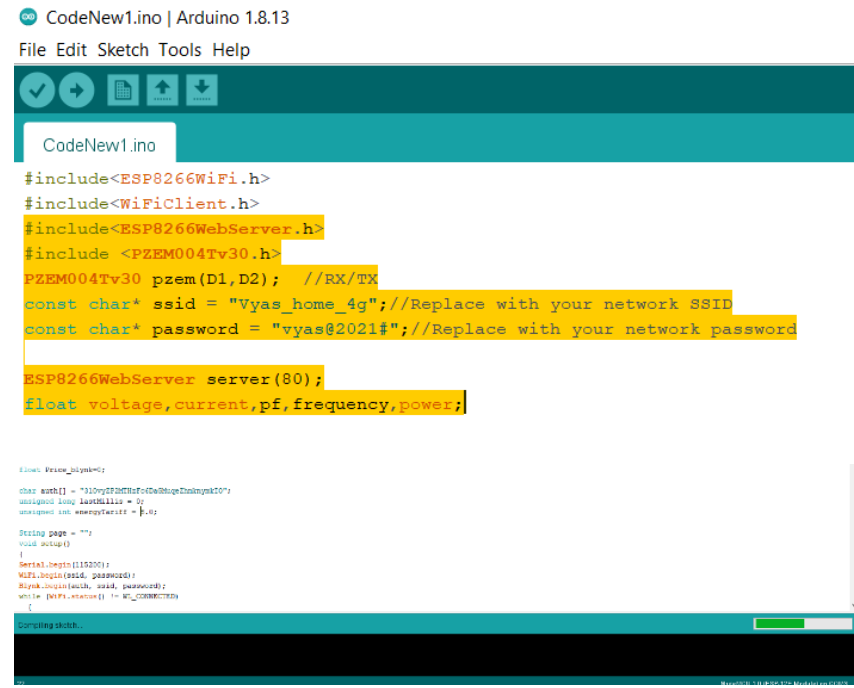

Figure 3. Coding Arduino interface

\begin{tabular}{|c|c|c|c|c|}
\hline$\epsilon \rightarrow \infty$. & 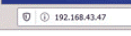 & & 可 & $\pm m \infty$ \\
\hline \multicolumn{5}{|c|}{ Smart Energy Meter using IoT } \\
\hline & Parameters & value & Units & \\
\hline & Voltage & 207.00 & Volts & \\
\hline & Current & 0.06 & Amper & \\
\hline & Power Factor & 1.00 & $\mathrm{xxxx}$ & \\
\hline & Power & 11.80 & Wats & \\
\hline & Frequency & 50.0 & Hz & \\
\hline
\end{tabular}

Figure 4. Web Monitoring

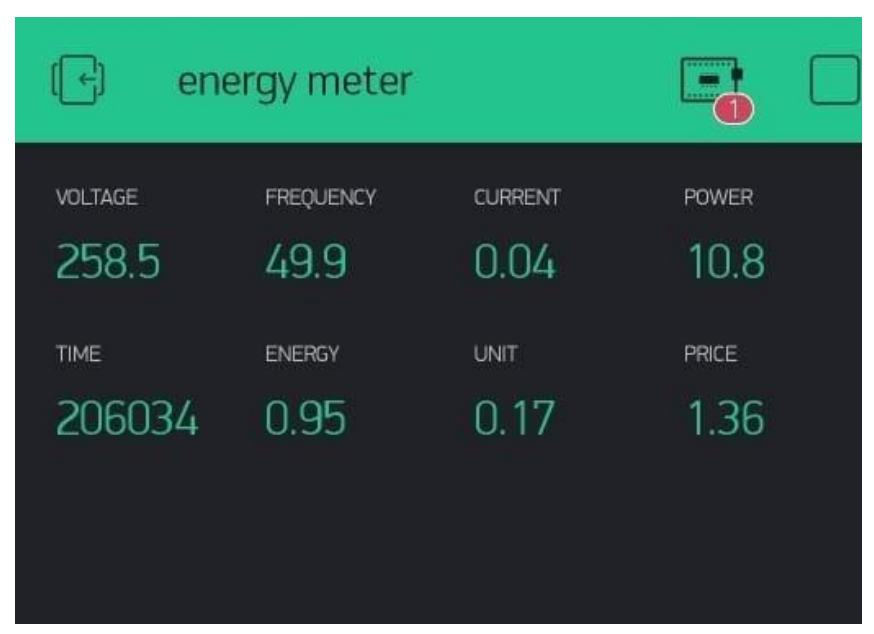

Figure 5. Blynk Monitoring

\section{CONCLUSION}

This IoT and ESP-8266 module-based energy meter use to access meter reading and bill amount by the use of web server and help consumer to avoid unwanted use of electricity as well as to detect any kind of theft of electricity. Following are the future scope in order to save electric power and to detect theft:-

- There can be a system where Automatic Switching of electric equipment by the use of IoT is applied.

- Create a system where consumers can receive SMS notifications if their electricity usage exceeds a certain threshold.

- Create an Internet of Things (IoT) system that allows users to track their energy usage and pay their electricity bills digitally.

- When a theft is detected at the consumer's end, the user receives a Notifications.

- Application of IoT based theft detection buzzer with Energy Meter.

\section{REFERENCES}

[1]. Amrita Singh, Ravi Gupta et. all 'IOT based smart energy meter', IEEE-2018.

[2]. Win Adiyansyah Indra, Fatimah Bt Morad, et. all 'GSM-Based Smart Energy Meter with Arduino Uno', IEEE-2018.

[3]. Lavanya Garg, Charul Sharma, et. all 'Iot Based Smart Energy Meter Using Arduino Avr And Node Mcu', IEEE-2018.

[4]. Pooja D Talwar1, Prof. S B Kulkarni 'Iot Based Energy Meter Reading', IEEE-2016.

[5]. K. Lova Raju, K. Yaswanth Pavankalyan, et. all 'Node MCU Based Power Monitoring and Smart Billing System Using IoT', IEEE-2020.

[6]. Martin Miskuf, Erik Kajati, et. all 'Smart metering IoT solution based on NodeMCU for more accurate energy consumption analysis', IEEE-2017. 
Arpanbhai Patel et al Int. J. Sci. Res. Comput. Sci. Eng. Inf. Technol, July-August-2021, 7 (4) : 125-131

[7]. D. V. N.Ananth, G. Joga Rao, et. all 'Smart Electricity Billing Using Node-MCU', IEEE2019.

[8]. Birendrakumar Sahani, Tejashree Ravi, et. all 'IoT Based Smart Energy Meter', IEEE-2017.

[9]. Somchai Thepphaeng, Varunyou Nontaboot, et. all 'Implementation of WiFi-Based Single Phase Smart Meter for Internet of Things (IoT)', IEEE-2017.

[10]. Rishabh Jain, Sharvi Gupta, et. all 'IOT based Smart Energy Meter Monitoring and Controlling System', IEEE-2019.

[11]. M. M. Mohamed Mufassirin, A. L. Hanees, 'Development Of Iot Based Smart Energy Meter Reading And Monitoring System', IEEE2018.

[12]. K. Lova Raju, K. Yaswanth Pavankalyan et. all 'Node MCU Based Power Monitoring and Smart Billing System Using IoT', IEEE-2020.

[13]. Shahajan Miah, G.M. Jahedul Islam et. all 'Internet of Things (IoT) based automatic electrical energy meter billing system', IEEE2019.

[14]. Somchai Thepphaeng, Varunyou Nontaboot, et. all 'Implementation of WiFi-Based Single Phase Smart Meter for Internet of Things (IoT)', IEEE-2017.

[15]. Satien Janpla1, Chaiwat Jewpanich, et. all 'The Smart Power Outlet System by Using the NodeMCU and Blynk IoT Platform', IEEE2020.

[16]. V.Badri Rama Krishnan, Keerthana Sandepudi, et. all 'An Optimised for energy monitoring and data acquisition and substation/domestic applications using IOT', IEEE-2019.

\section{Cite this article as :}

Arpanbhai Patel, Dhwani Darji, "IoT Smart Energy Meter Monitoring with Web and Blynk App", International Journal of Scientific Research in Computer Science, Engineering and Information Technology (IJSRCSEIT), ISSN : 2456-3307, Volume 7 Issue 4, pp. 125-131, July-August 2021. Available at doi : https://doi.org/10.32628/CSEIT217431 Journal URL : https://ijsrcseit.com/CSEIT217431 